Arquives

do Instituto Biológico

SCIENTIFIC ARTICLE

Plant Health

\title{
Phytochemical profile and antifungal action of Anadenanthera colubrina extract on the quality of maize seeds
}

\author{
José George Ferreira Medeiros ${ }^{1}$ (D) https://orcid.org/0000-0002-7056-0789 \\ Aderson Costa Araujo Neto ${ }^{2, *}$ (i) https://orcid.org/0000-0003-1941-9568 \\ Edcarlos Camilo Silva ${ }^{3}$ (D) https://orcid.org/0000-0001-9990-8630 \\ Rummenigge de Macêdo Rodrigues ${ }^{3}$ (1) https://orcid.org/0000-0003-1595-9567 \\ Andréa Celina Ferreira Demartelaere ${ }^{4}$ (D) https://orcid.org/0000-0003-0427-0916 \\ José Vinicius Bezerra da Silva1 (1) https://orcid.org/0000-0003-0726-9347 \\ 1. Universidade Federal de Campina Grande - Centro de Desenvolvimento Sustentável do Semiárido - Sumé (PB), Brazil. \\ 2. Prefeitura Municipal de Itatiba - Secretaria de Meio Ambiente e Agricultura - Seção de Áreas Verdes - Itatiba (SP), Brazil. \\ 3. Universidade Federal da Paraíba - Centro de Ciências Agrárias - Departamento de Fitotecnia e Ciências Ambientais - Areia (PB), Brazil. \\ 4. Escola Técnica Estadual Senador Jessé Pinto Freire - Parazinho (RN), Brazil. \\ *Corresponding author: adersoncaneto@gmail.com
}

\section{ABSTRACT}

Maize (Zea mays L.) is among the most cultivated crops in the world and can be affected by several diseases, especially those transmitted by seeds. The study of alternatives to fungicides used for seed treatment has a promising field in essential oils. Thus, this study determined the phytochemical profile of the ethanolic extract from Anadenanthera colubrina (Vell.) Brenan and to evaluate its antifungal activity on the sanitary and physiological quality of maize seeds. The seeds used were of the Jaboatão cultivar, which were submitted to the following treatments: control (untreated seeds), commercial fungicide (dicarboximide) and A. colubrina extract at $200,400,600,800$, and $1,000 \mathrm{ppm}$. The seeds were subjected to sanitary and germination tests in a completely randomized experimental design. Phytochemical prospecting of $A$. colubrina extract indicated the presence of alkaloids, tannins, flavonoids and saponins, as well as the major compounds lupeol, gallic acid, ferulic acid, catechin and quercetin. The A. colubrina extract reduced the incidence of Aspergillus spp., including Aspergillus niger, Alternaria spp., Curvularia spp. and Fusarium spp. at all concentrations. The highest concentrations ( 800 and 1,000 ppm) of the $A$. colubrina extract reduced the incidence of Penicillium spp. and yielded an effective control of Rhizoctonia spp. The extract of $A$. colubrina did not present phytotoxic effect, guaranteeing the viability and vigor of maize seeds.

Keywords: secondary metabolites; seed pathology; alternative control.

\section{INTRODUCTION}

Maize (Zea mays L.) is one of the most cultivated crops in the world, with wide adaptability to different edaphoclimatic conditions (DOMENE et al., 2016). In Brazil, in the 2016/2017 harvest, about 16,772 million hectares were sown and approximately 88,969 million tons of grain were produced (CONAB, 2017).

The health quality of seeds can be compromised by the association of fungi in all production stages. These pathogens are frequently responsible for the reduction in their physiological quality and can be disseminated over long distances through infected seeds and be transmitted via seed-seedlings (SALES et al., 2016).

Among the fungal diseases that affect the maize crop, those that cause seed rot and seedling damping-off in pre- and post-emergence are of great importance, as they are responsible for the reduction or total loss in yield, in addition to the significant increase in production costs (STEFANELLO et al., 2012). Fusarium verticillioides, Stenocarpella maydis, Rhizoctonia spp., Penicillium oxalicum and Pythium spp. are the main causal agents of this group of diseases, and these pathogens survive in the soil and inside seeds, that is, they are optional parasites (MACHADO et al., 2013).

Received: Oct 18, 2019 Accepted: Oct 24, 2020

Associate Editor: Silvia Galleti

Peer Review History: Double-blind Peer Review. 
The exploration of the biological activity of secondary compounds, present in the plant crude extract or essential oils, can constitute, alongside biological control and resistance induction, in yet another potential form of alternative control (SOUZA et al., 2013). Several studies using plant extracts and essential oils have been conducted in the control of phytopathogens as an alternative to the use of synthetic pesticides (LORENZETTI et al., 2011; VENTUROSO et al., 2011); they have demonstrated efficiency in the control of rot and pathogens linked to seeds in maize (GURJAR et al., 2012).

The evaluation of the sanitary quality of seeds using plant extracts and/or essential oils has been carried out by several authors such as FLÁVIO et al. (2014), GOMES et al. (2016) and MEDEIROS et al. (2016), who concluded that these products, in addition to reducing the occurrence of fungal species, result in improvements in the germinability of the treated seeds.

The Caatinga vegetation has great botanical potential, but it is little explored regarding the knowledge of the biochemical constitution and biological control. Among the species of this biome, Anadenanthera colubrina (Vell.) Brenan, popularly known as angico, stands out for its wide distribution, abundance and use as a phytomedicine in popular medicine. This species contains compounds involved in chemical defense that include lectins, protease and amylase inhibitors, toxins and secondary metabolites of low molecular weight (RIEGELHAUPT; PAREYN, 2013).

In this context, aiming to explore the biochemical potential of Caatinga species and in view of the need for new alternatives to control fungi associated with seeds, this study aimed to determine the phytochemical profile of the ethanolic extract from A. colubrina and to evaluate its antifungal activity on sanitary and physiological quality of maize seeds.

\section{MATERIAL AND METHODS}

The experiment was conducted at the Semiarid Plant Health Laboratory (LAFISA), belonging to the Semiarid Sustainable Development Center (CDSA) of Universidade Federal de Campina Grande (UFCG), located in the municipality of Sumé, $\mathrm{PB}$, Western Cariri micro region $\left(07^{\circ} 40^{\prime} 18^{\prime \prime} \mathrm{S}\right.$ and $\left.36^{\circ} 52^{\prime} 48^{\prime \prime} \mathrm{W}\right)$.

The maize seeds used were of the Jaboatão cultivar, from the municipality of São José dos Cordeiros/PB, belonging to the 2017 harvest. After the samples were taken to the LAFISA, the seeds were subjected to purity analysis, eliminating crop remains and deteriorated seeds.

\section{Obtention of Anadenanthera colubrina ethanolic extract}

For the obtention of A. colubrina extract, the cold extraction method was used, as proposed by MEDEIROS et al. (2016), in which the plant material (leaves) was dried in an oven at $40{ }^{\circ} \mathrm{C}$ for $72 \mathrm{~h}$ and, subsequently, crushed in a knife mill to obtain the plant powder; $150 \mathrm{~g}$ of plant powder were used, immersed in a beaker containing $0.5 \mathrm{~L}$ of absolute ethanol for $72 \mathrm{~h}$ at room temperature $\left(25 \pm 2{ }^{\circ} \mathrm{C}\right)$; the solution was filtered through filter paper. After the procedure, the solvent was left for $10 \mathrm{~h}$ in an oven with a ventilation system at $70^{\circ} \mathrm{C}$ for the obtention of the crude ethanolic extract. The crude extract was diluted at the concentrations used, 200, 400, 600, 800, and 1,000 ppm.

\section{Phytochemical prospecting of Anadenanthera colubrina extract}

Anadenanthera colubrina extract was subjected to phytochemical characterization reactions, which were carried out according to the following methodologies:

a) Alkaloids: $25.0 \mathrm{~mL}$ of the ethanolic extract were evaporated, alkalinizing with $0.8 \mathrm{~mL}$ of $1.0 \%$ sodium hydroxide $(\mathrm{NaOH})$. Subsequently, $6.0 \mathrm{~mL}$ of distilled water were added with $6.0 \mathrm{~mL}$ of chloroform $\left(\mathrm{CHCl}_{3}\right)$; the solution was then placed in a funnel for separation between the extract and the chloroform layer. $6.0 \mathrm{~mL}$ of hydrochloric acid $(1.0 \% \mathrm{HCl})$ and $0.3 \mathrm{~mL}$ of Dragendorff's reagent were added to the chloroform phase (WU et al., 2005).

b) Tannins: were determined by the casein precipitation method, which consisted of adding $1.0 \mathrm{~g}$ of powdered casein and $6.0 \mathrm{~mL}$ of the extract diluted in $12.0 \mathrm{~mL}$ of distilled water in a $50.0-\mathrm{mL}$ conical flask, kept under constant stirring for $3 \mathrm{~h}$ at room temperature $\left(25 \pm 2{ }^{\circ} \mathrm{C}\right)$. Subsequently, the sample was filtered on filter paper and the volume of the resulting filtrate was made up to $25.0 \mathrm{~mL} ; 5.0-\mathrm{mL}$ aliquots were removed from this solution and residual phenols were determined by the Folin-Ciocalteu method (PEIXOTO SOBRINHO et al., 2010).

c) Flavonoids: $15 \mathrm{~mL}$ of ethanolic extract were placed in a separatory funnel, and $15 \mathrm{~mL}$ of distilled water were added. The solution was then left to stand for $10 \mathrm{~min}$, where $15.0 \mathrm{~mL}$ of $\mathrm{CHCl}_{3}$ were added. After $5 \mathrm{~min}$ of the addition of chloroform, the layers were separated, disregarding the chloroform layer. The remaining extract was isolated and $3.0 \mathrm{~mL}$ of ethanol 
were added, a 2.0-mL aliquot of this solution was collected in a test tube. In the tube, $0.5 \mathrm{~mL}$ of $10.0 \% \mathrm{HCl}$ (hydrochloric acid) and $1.0 \mathrm{~cm}$ of magnesium tape were added, allowing the reaction until disappearance (CHUN et al., 2004).

d) Saponins: $0.25 \mathrm{~mL}$ of the ethanolic extract were placed in a test tube with distilled water and stirred well until foam was formed; $10 \mathrm{~min}$ were waited and it was observed if the foam remained or was not present. The presence of saponins indicates that the substance is highly soluble in water (VIEIRA et al., 2001).

Major secondary compounds were identified using gas chromatography (GC-MS).

\section{Maize seed treatment and health testing}

In the health test, 200 seeds were used per treatment, distributed in 10 replications of 20 seeds each. The seeds were subjected to asepsis with sodium hypochlorite (1.0\%) for $3 \mathrm{~min}$, immersed in $10.0 \mathrm{~mL}$ of the different concentrations of A. colubrina extract for $5 \mathrm{~min}$ and distributed in Petri dishes on a double layer of sterile filter and moistened with sterile distilled water. The dishes remained for seven days at a temperature of $25 \pm 2{ }^{\circ} \mathrm{C}$ (ZAUZA et al., 2007).

The treatments applied to the seeds consisted of $\mathrm{T}_{1}$ : control (untreated seeds); $\mathrm{T}_{2}$ : fungicide dicarboximide, commercial formulation Captan (240 g i.a. $\cdot 100 \mathrm{~kg}^{-1}$ seeds); $\mathrm{T}_{3}:$ A. colubrina extract (EAc) at $200 \mathrm{ppm} ; \mathrm{T}_{4}: 400 \mathrm{ppm} \mathrm{EAc;} \mathrm{T}_{5}: 600 \mathrm{ppm}$ EAc; $\mathrm{T}_{6}: 800 \mathrm{ppm} \mathrm{EAc}$ and $\mathrm{T}_{7}: 1,000 \mathrm{ppm} \mathrm{EAc.}$

The fungi were detected and identified with the aid of an optical microscope and stereoscope, being compared to the descriptions in the literature (SEIFERT et al., 2011) and the results were expressed as a percentage of infected seeds for each identified fungus.

\section{Germination test}

For the germination test, the same treatments applied in the health test were used: 200 seeds were used, subdivided into four replications of 50 seeds per treatment, which were sown on previously sterilized germitest paper and moistened with distilled water in the proportion of 2.5 times its dry weight, and incubated in biochemical oxygen demand (BOD) at $27^{\circ} \mathrm{C}$ and a 12 -hour photoperiod. The counts of germinated and non germinated seeds were performed from the fourth to the seventh day after sowing and the evaluations were carried out according to the criteria established by the Rules for Seed Analysis (BRAZIL, 2009).

In the germination test, the germination percentages, dead seeds, hard seeds and the germination speed index (GSI) were evaluated. The GSI was evaluated together with the germination test, carrying out daily counts of normal seedlings according to the formula proposed by MAGUIRE (1962) (Eq. 1):

$$
\mathrm{GSI}=(\mathrm{G} 1 / \mathrm{N} 1)+(\mathrm{G} 2 / \mathrm{N} 2)+(\mathrm{G} 3 / \mathrm{N} 3)+\ldots+(\mathrm{Gn} / \mathrm{Nn})
$$

where, G1, G2, G3, and Gn = number of seedlings computed in the first, second, third, and last count; N1, N2, N3, and $\mathrm{N}_{\mathrm{n}}$ = number of days from sowing to first, second, third, and last count.

\section{Experimental design and statistical analysis}

The experimental design used was completely randomized, totaling seven treatments. The health test consisted of ten replications of 20 seeds each, while the germination test was performed on four replications of 50 seeds per treatment. The data were submitted to analysis of variance by the F test, and the means were compared by the Tukey's test ( $\mathrm{p} \leq 0.05)$, using the ASSISTAT statistical software.

\section{RESULTS AND DISCUSSION}

The phytochemical profile of the ethanolic extract of A. colubrina showed the presence of different groups of secondary metabolites, suggesting the availability of alkaloids, tannins, flavonoids and saponins. In general, the studied species suggests potential for antimicrobial activity due to the reported phytochemical constituents, which may be associated with antioxidant and antimicrobial activity (SOUZA et al., 2013).

The chemical constituents present in A. colubrina extract may account for the majority of its biological activity, although its form of action is normally combined with a certain bioactivity. Therefore, it is important to highlight its main property, for example, the ability to neutralize free radicals generated in the cell (BESSA et al., 2013). 
The secondary compounds identified in the A. colubrina extract at considerable levels were lupeol, gallic acid, ferulic acid, catechin (polyphenol) and quercetin (flavonoid) (Table 1).

Table 1. Secondary compounds present in the ethanolic extract of $A$. colubrina, expressed in $\mathrm{mg} / 10 \mathrm{~g}$ of crude extract.

\begin{tabular}{lccccc}
\hline Extract & Lupeol $^{*}$ & Gallic acid & Ferulic acid & Catechin & Quercetin $^{*}$ \\
\hline EAc $^{* *}$ & 11.2 & 2.2 & 0.9 & 7.6 & 12.0 \\
\hline
\end{tabular}

"Identified through GC-MS. "* EAc: Anadenanthera colubrina extract.

According to JEFFREYS; NUNEZ (2016), lupeol is a triterpene that has an antimicrobial effect and its reactions are catalyzed by the enzyme lupeol synthase. Gallic acid is a phenolic compound of great importance in plant defense and a reference standard for the quantification of total phenolics; its antimicrobial activity has already been proven (MORAIS et al., 2016). Meanwhile, ferulic acid is related to cell wall resistance.

The determination of the chromatographic profile of the ethanolic extract from A. colubrina can be seen in Figure 1. Observing the retention times, the following majoritarian compounds were verified: palmitic acid (13.339 min); $\alpha$-linolenic acid (14.893 min); ferulic acid (14.933 min); catechin (15.142 min); lupeol (15.441 min) and quercetin (18.357 min). Several complex molecules such as those mentioned above are synthesized by the secondary metabolism of plants and are of great importance in the plant-phytopathogen relationship.

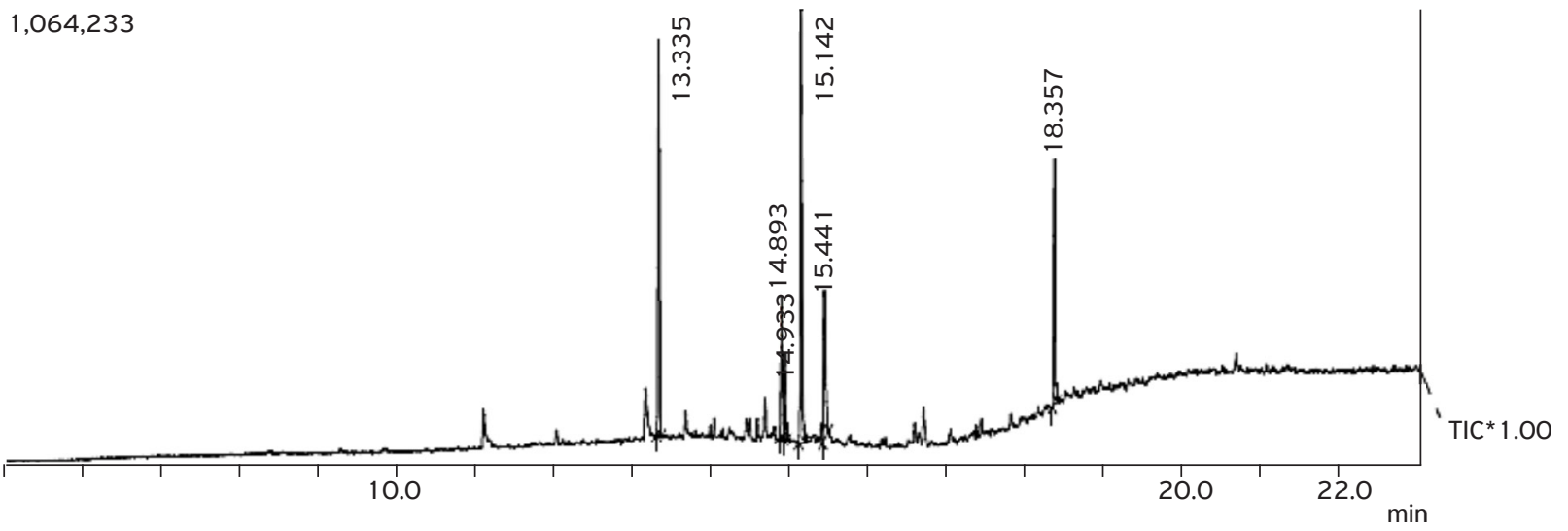

Figure 1. Chromatographic profile and retention time of major compounds in the ethanolic extract of $A$. colubrina.

In the sanitary evaluation of maize seeds, storage fungi Aspergillus spp., especially Aspergillus niger, and Penicillium spp. were detected (Table 2). Regarding the incidence of A. niger and Aspergillus spp., it was observed that all treatments were efficient in reducing the occurrence of these fungi in relation to the control $\left(\mathrm{T}_{1}\right)$. A similar effect was observed by DOMENE et al. (2016), who verified a reduction in the incidence of fungi of the genera Penicillium, Fusarium and Aspergillus in maize seeds when treated with eucalyptus essential oil (Eucalyptus camaldulensis), equivalent to the commercial fungicide Captan 500.

As for the occurrence of Penicillium spp., it was observed that seeds treated with commercial fungicide $\left(\mathrm{T}_{2}\right)$ and A. colubrina extract at a concentration of $1,000 \mathrm{ppm}\left(\mathrm{T}_{7}\right)$ had a significant reduction in the incidence of this fungus, when compared to the other treatments (Table 2).

Table 2. Incidence of storage fungi associated with maize seeds submitted to treatments with the ethanolic extract of $A$. colubrina.

\begin{tabular}{lccc}
\hline Treatments & Aspergillus niger (\%) & Aspergillus spp. (\%) & Penicillium spp. (\%) \\
\hline $\mathrm{T}_{1}$ - Control & $33.0 \mathrm{a}^{*}$ & $64.0 \mathrm{a}$ & $35.0 \mathrm{a}$ \\
\hline $\mathrm{T}_{2}$ - Commercial fungicide & $0.0 \mathrm{~cd}$ & $2.0 \mathrm{~d}$ & $0.0 \mathrm{~d}$ \\
\hline $\mathrm{T}_{3}-\mathrm{EAc} 200 \mathrm{ppm}$ & $18.0 \mathrm{~b}$ & $21.0 \mathrm{~b}$ & $31.0 \mathrm{a}$ \\
\hline $\mathrm{T}_{4}-\mathrm{EAc} 400 \mathrm{ppm}$ & $5.0 \mathrm{c}$ & $17.0 \mathrm{bc}$ & $30.0 \mathrm{a}$ \\
\hline $\mathrm{T}_{5}-\mathrm{EAc} 600 \mathrm{ppm}$ & $0.0 \mathrm{~cd}$ & $2.0 \mathrm{~d}$ & $26.0 \mathrm{a}$ \\
\hline $\mathrm{T}_{6}-\mathrm{EAc} 800 \mathrm{ppm}$ & $0.0 \mathrm{~cd}$ & $5.0 \mathrm{~d}$ & $19.0 \mathrm{ab}$ \\
\hline $\mathrm{T}_{7}-\mathrm{EAc} 1,000 \mathrm{ppm}$ & $0.0 \mathrm{~cd}$ & $5.0 \mathrm{~d}$ & $12.0 \mathrm{c}$ \\
\hline $\mathrm{CV}(\%)$ & 41.3 & 34.5 & 21.2 \\
\hline
\end{tabular}

"Means followed by the same letter in the column do not differ by the Tukey test at $5 \%$ probability. EAc: $A$. colubrina extract. 
The antifungal activity of $A$. colubrina extract may be related to the presence of terpenes, such as lupeol (Table 2), whose mechanisms of action of this class of compounds involve the rupture of the plasma membrane and the accumulation of reactive oxygen species (ROS) induced by mitochondrial dysfunction, with consequent cell death (LAGROUH et al., 2017).

According to MACHINSKI JUNIOR et al. (2001), the mycotoxins that can be found in maize grains are produced mainly by Penicillium spp. (ochratoxin) and Aspergillus spp. (aflatoxins and ochratoxin), which can cause risks to human and animal health. The occurrence of these fungi immediately after harvest was also reported by STEFANELLO et al. (2012); however, its incidence can show wide variations, as a function of genotype or climatic conditions.

The percentage of fungal incidence commonly related to diseases of maize shoots, represented in this study by Alternaria spp., Colletotrichum spp. and Curvularia spp., are shown in Table 3. For Alternaria spp. and Curvularia spp., it was found that all treatments with extract were efficient in reducing the occurrence of these fungi, being equivalent to the commercial fungicide $\left(\mathrm{T}_{2}\right)$ and differing statistically from the control $\left(\mathrm{T}_{1}\right)$. Regarding the incidence of Colletotrichum spp. there was no significant difference between the treatments applied.

Table 3. Incidence of disease-causing fungi detected in maize seeds submitted to treatments with the ethanolic extract of $A$. colubrina.

\begin{tabular}{|c|c|c|c|}
\hline Treatments & Alternaria spp. (\%) & Colletotrichum spp. (\%) & Curvularia spp. (\%) \\
\hline $\mathrm{T}_{1}$ - Control & $13.0 a^{*}$ & $4.0 \mathrm{a}$ & $17.0 \mathrm{a}$ \\
\hline $\mathrm{T}_{2}$ - Commercial fungicide & $0.0 \mathrm{c}$ & $0.0 \mathrm{a}$ & $1.0 \mathrm{bc}$ \\
\hline $\mathrm{T}_{3}-\mathrm{EAc} 200 \mathrm{ppm}$ & $6.0 \mathrm{~b}$ & $0.0 \mathrm{a}$ & $5.0 \mathrm{~b}$ \\
\hline $\mathrm{T}_{4}-\mathrm{EAc} 400 \mathrm{ppm}$ & $7.0 \mathrm{~b}$ & $0.0 \mathrm{a}$ & $1.0 \mathrm{bc}$ \\
\hline $\mathrm{T}_{5}-\mathrm{EAc} 600 \mathrm{ppm}$ & $1.0 \mathrm{c}$ & $0.0 \mathrm{a}$ & $0.0 \mathrm{c}$ \\
\hline $\mathrm{T}_{6}-\mathrm{EAc} 800 \mathrm{ppm}$ & $0.0 \mathrm{c}$ & $0.0 \mathrm{a}$ & $0.0 \mathrm{c}$ \\
\hline $\mathrm{T}_{7}-\mathrm{EAc} 1,000 \mathrm{ppm}$ & $0.0 \mathrm{c}$ & $0.0 \mathrm{a}$ & $0.0 \mathrm{c}$ \\
\hline CV (\%) & 12.6 & 18.2 & 20.4 \\
\hline
\end{tabular}

"Means followed by the same letter in the column do not differ by the Tukey's test at $5 \%$ probability. EAc: $A$. colubrina extract.

According to SALES et al. (2016), the inhibitory effect of plant extracts on fungal reduction is related to the presence of natural bioactive compounds present in their composition, such as those identified in the A. colubrina extract (Table 1), highlighting lupeol and gallic acid, for having antimicrobial properties. VENTUROSO et al. (2011) found that the aqueous extract of clove (Syzygium aromaticum L.) completely inhibited the in vitro development of all studied phytopathogens (Aspergillus sp., Penicillium sp., Colletotrichum sp., Fusarium solani, Cercospora kikuchii and Phomopsis sp.). This antifungal action is attributed to the presence of eugenol, a major component of clove (LORENZETTI et al., 2011).

Associated with maize seeds, fungi considered to be soil fungi, such as Fusarium spp., Rhizoctonia spp. and Pythium spp., were also identified (Table 4). All treatments tested differed from the control $\left(\mathrm{T}_{1}\right)$ in reducing the percentage of Fusarium spp. incidence, highlighting those applied with the highest extract concentrations (800 and 1,000 ppm), which yielded an effective control of this fungus. This reduction in the occurrence of Fusarium spp. was also observed by GOMES et al. (2016) in fava bean seeds treated with essential oils of diesel tree (Copaifera langsdorffi) and basil (Ocimum basilicum), both at a concentration of $2 \mathrm{ml} \cdot \mathrm{L}^{-1}$.

Table 4. Incidence of soil fungi detected in maize seeds submitted to treatments with the ethanolic extract of $A$. colubrina.

\begin{tabular}{lccc}
\hline Treatments & Fusarium (\%) & Rhizoctonia spp. (\%) & Pythium spp. (\%) \\
\hline $\mathrm{T}_{1}$ - Control & $24.0 \mathrm{a}^{*}$ & $12.0 \mathrm{a}$ & $4.0 \mathrm{a}$ \\
\hline $\mathrm{T}_{2}$ - Commercial fungicide & $0.0 \mathrm{~d}$ & $0.0 \mathrm{c}$ & $0.0 \mathrm{a}$ \\
\hline $\mathrm{T}_{3}-\mathrm{EAc} 200 \mathrm{ppm}$ & $13.0 \mathrm{~b}$ & $8.0 \mathrm{~b}$ & $0.0 \mathrm{a}$ \\
\hline $\mathrm{T}_{4}-\mathrm{EAc} 400 \mathrm{ppm}$ & $6.0 \mathrm{c}$ & $10.0 \mathrm{ab}$ & $0.0 \mathrm{a}$ \\
\hline $\mathrm{T}_{5}-\mathrm{EAc} 600 \mathrm{ppm}$ & $1.0 \mathrm{~d}$ & $3.0 \mathrm{c}$ & $0.0 \mathrm{a}$ \\
\hline $\mathrm{T}_{6}-\mathrm{EAc} 800 \mathrm{ppm}$ & $0.0 \mathrm{~d}$ & $0.0 \mathrm{c}$ & $0.0 \mathrm{a}$ \\
\hline $\mathrm{T}_{7}-\mathrm{EAc} 1,000 \mathrm{ppm}$ & $0.0 \mathrm{~d}$ & $0.0 \mathrm{c}$ & $0.0 \mathrm{a}$ \\
\hline $\mathrm{CV}(\%)$ & 19.0 & 24.0 & 14.3 \\
\hline
\end{tabular}

"Means followed by the same letter in the column do not differ by the Tukey's test at $5 \%$ probability. EAc: A. colubrina extract.

The seeds treated with commercial fungicide $\left(\mathrm{T}_{2}\right)$ and A. colubrina extract at $600\left(\mathrm{~T}_{5}\right), 800\left(\mathrm{~T}_{6}\right)$ and 1,000 $\left(\mathrm{T}_{7}\right) \mathrm{ppm}$ showed a lower occurrence and control of the fungus Rhizoctonia spp., when compared to the other treatments, differing 
significantly from the control $\left(\mathrm{T}_{1}\right)$. These results demonstrate the effectiveness of the antifungal action of $A$. colubrina extract on the development of these phytopathogens. For the development of Pythium spp., there was no significant difference between the analyzed treatments (Table 4).

The use of plant extracts and essential oils as potent natural fungicides has shown promising results in the control of several phytopathogens, such as the reduction in the incidence of fungi of the genera Curvularia and Fusarium in sorghum seeds treated with aqueous cinnamon extract (Cinnamomum zeylanicum) (FLÁVIO et al., 2014). According to SALES et al. (2016), several complex molecules are synthesized by the secondary metabolism of plants and are of great importance in the control of plant diseases. Among the most important metabolites, alkaloids, quinones, flavonoids, glycosides, saponins, tannins and terpenoids are particularly noteworthy, some of which are present in A. colubrina extract.

Fusarium fungi can survive in the soil through resistance structures and also in internal seed structures, such as the embryo, in addition to being able to produce a variety of mycotoxins, among them, fusaric acid (MACHADO et al., 2013). The genus Rhizoctonia comprises a group of fungi that survive saprophytically in the soil in the form of mycelium and sclerotia, which can be transmitted to seedlings via seeds, causing root problems and seedling damping-off (LAZAROTTO et al., 2012).

Regarding the results for the germination test, it was found that maize seeds treated with A. colubrina extract at $200\left(\mathrm{~T}_{3}\right)$, $400\left(\mathrm{~T}_{4}\right)$ and $600\left(\mathrm{~T}_{5}\right)$ ppm showed a significant increase in the percentage of germination, with an increase of $8.0 \%$ in relation to the control $\left(\mathrm{T}_{1}\right)$, although without differing from other treatments. Treatments with A. colubrina extract, regardless of concentration, led to a significant reduction in the percentage of dead seeds, when compared to the control (Table 5).

Table 5. Average values of germination, dead seeds, hard seeds and germination speed index (GSI) of maize seeds submitted to treatments with the ethanolic extract of $A$. colubrina.

\begin{tabular}{|c|c|c|c|c|}
\hline Treatments & Germination (\%) & Dead seeds (\%) & Hard seeds (\%) & GSI (\%) \\
\hline $\mathrm{T}_{1}$ - Control & $92.0 b^{*}$ & $8.0 \mathrm{a}$ & $0.0 \mathrm{a}$ & $6.6 \mathrm{a}$ \\
\hline $\mathrm{T}_{2}$ - Commercial fungicide & $98.0 \mathrm{ab}$ & $2.0 \mathrm{~b}$ & $0.0 \mathrm{a}$ & $8.8 \mathrm{a}$ \\
\hline $\mathrm{T}_{3}-\mathrm{EAc} 200 \mathrm{ppm}$ & $100.0 \mathrm{a}$ & $0.0 \mathrm{~b}$ & $0.0 \mathrm{a}$ & $9.1 \mathrm{a}$ \\
\hline $\mathrm{T}_{4}-\mathrm{EAc} 400 \mathrm{ppm}$ & $100.0 \mathrm{a}$ & $0.0 \mathrm{~b}$ & $0.0 \mathrm{a}$ & $10.2 \mathrm{a}$ \\
\hline $\mathrm{T}_{5}-\mathrm{EAc} 600 \mathrm{ppm}$ & $100.0 \mathrm{a}$ & $0.0 \mathrm{~b}$ & $0.0 \mathrm{a}$ & $9.3 \mathrm{a}$ \\
\hline $\mathrm{T}_{6}-\mathrm{EAc} 800 \mathrm{ppm}$ & $98.0 \mathrm{ab}$ & $2.0 \mathrm{~b}$ & $0.0 \mathrm{a}$ & $8.4 \mathrm{a}$ \\
\hline $\mathrm{T}_{7}-\mathrm{EAc} 1,000 \mathrm{ppm}$ & $98.0 \mathrm{ab}$ & $2.0 \mathrm{~b}$ & $0.0 \mathrm{a}$ & $7.8 \mathrm{a}$ \\
\hline CV (\%) & 15.92 & 12.85 & 0.0 & 6.72 \\
\hline
\end{tabular}

"Means followed by the same letter in the column do not differ by the Tukey's test at $5 \%$ probability. EAc: A. colubrina extract.

These results prove the potential of the antifungal activity of $A$. colubrina extract determined in the sanitary analysis of the seeds (Tables 2, 3 and 4), due to the fact that the efficient control of mycoflora associated with maize seeds results in an increase in their germination capacity. Different results were found by FLÁVIO et al. (2014), who concluded that the treatments with aqueous cinnamon extract (C. zeylanicum) and clove basil essential oil (Ocimum gratissimum) presented a phytotoxic effect, reducing the viability and vigor of sorghum seeds.

For the variables percentage of hard seeds and germination speed index (GSI), there were no significant differences between the treatments evaluated (Table 5), which indicates that germinability and germination speed were not affected by the $A$. colubrina extract. This is possibly due to the fact that this treatment does not have an allelopathic effect on maize germination. Similarly, GOMES et al. (2016) did not verify the influence of treatments with essential oils of diesel tree (C. langsdorffii), clove (Caryophyllus aromaticus) and basil (O. basilicum) on the germination and germination speed of fava beans.

In general, through the obtained results, it can be inferred that the ethanolic extract of $A$. colubrina is a viable alternative in the control of mycoflora associated with maize seeds, favoring their germinability, due to the presence of substances with fungicidal properties in its composition. For MEDEIROS et al. (2016), seeds predisposed to the action of microorganisms, when treated, reduce the ability of phytopathogens to survive and enhance seed longevity, their germinative power and the vigor of future plants.

\section{CONCLUSIONS}

The phytochemical profile of the ethanolic extract from A. colubrina indicated the presence of alkaloids, tannins, flavonoids and saponins, in addition to the major compounds lupeol, gallic acid, ferulic acid, catechin and quercetin. 
Anadenanthera colubrina extract reduced the incidence of Aspergillus spp., including Aspergillus niger, Alternaria spp., Curvularia spp. and Fusarium spp. at all concentrations.

The highest concentrations ( 800 and 1,000 ppm) of $A$. colubrina extract reduced the incidence of Penicillium spp. and yielded an effective control of Rhizoctonia spp.

Anadenanthera colubrina extract had no phytotoxic effect, guaranteeing the germinability of maize seeds.

\section{AUTHORS' CONTRIBUTIONS}

Conceptualization: Medeiros, J.G.F.; Silva, J.V.B. Data curation: Medeiros, J.G.F.; Araujo Neto, A.C. Formal analysis: Araujo Neto, A.C.; Demartelaere, A.C.F. Investigation: Silva, E.C.; Rodrigues, R.M.; Silva, J.V.B. Project administration: Medeiros, J.G.F. Supervision: Medeiros, J.G.F. Validation: Araujo Neto, A.C.; Demartelaere, A.C.F., Writing - original draft: Araujo Neto, A.C.; Demartelaere, A.C.F.; Medeiros, J.G.F. Writing - review \& editing: Araujo Neto, A.C.; Silva, J.V.B.

\section{AVAILABILITY OF DATA AND MATERIAL}

The datasets generated and/or analyzed during the current study are available from the corresponding author on reasonable request.

\section{FUNDING}

This work did not receive any specific grant from funding agencies in the public, commercial, or not-for-profit sectors.

\section{CONFLICTS OF INTEREST}

All authors declare that they have no conflict of interest.

ETHICAL APPROVAL

Not applicable.

ACKNOWLEDGEMENTS

Not applicable.

\section{REFERENCES}

[CONAB] Companhia Nacional de Abastecimento. Compêndio de Estudos Conab. Sexto levantamento. Brasilia: Conab, 2017. Available from: https://www.conab.gov.br/index.php/institucional/publicacoes/compendio-de-estudos-da-conab. Access on: 25 Sep. 2019.

BESSA, N.G.F.; BORGES, J.C.M.; BESERRA, F.P.; CARVALHO, R.H.A.; PEREIRA, M.A.B.; FAGUNDES, R.; CAMPOS, S.L.; RIBEIRO, L.U.; QUIRINO, M.S.; CHAGAS JUNIOR, A. F.; ALVES, A. Prospecção fitoquímica preliminar de plantas nativas do cerrado de uso popular medicinal pela comunidade rural do assentamento vale verde - Tocantins. Revista Brasileira de Plantas Medicinais, Botucatu, v.15, n.4, p.692-707, 2013. Suppl. 1. https://doi.org/10.1590/S1516-05722013000500010

BRAZIL. Ministério da Agricultura, Pecuária e Abastecimento. Regras para Análise de Sementes. Brasília: MAPA/ACS, 2009. 399p. Available from: https://www.gov.br/agricultura/pt-br/assuntos/insumos-agropecuarios/arquivos-publicacoes-insumos/2946_regras_analise_sementes. pdf. Access on: 15 Sep. 2019.

CHUN, O.K.; SMITH, N.; SAKAGAWA, A.; LEE, C.Y. Antioxidant properties of raw and processed cabbages. International Journal of Food Sciences and Nutrition, Parma, v.55, n.3, p.191-199, 2004. https://doi.org/10.1080/09637480410001725148

DOMENE, M.P., GLÓRIA, E.M., BIAGI, J.D., BENEDETTI, B.C., MARTINS, L. Efeito do tratamento com óleos essenciais sobre a qualidade fisiológica e sanitária das sementes de milho (Zea mays). Arquivos do Instituto Biológico, São Paulo, v.83, p.1-6, 2016. https:// doi.org/10.1590/1808-1657000072014

FLÁVIO, N.S.D.S.; SALES, N.L.P.; AQUINO, C.F.; SOARES, E.P.S.; AQUINO, L.F.S.; CATÃO, H.C.R.M. Qualidade sanitária e fisiológica de sementes de sorgo tratadas com extratos aquosos e óleos essenciais. Semina: Ciências Agrárias, Londrina, v.35, n.1, p.7-20, 2014. https:// doi.org/10.5433/1679-0359.2014v35n1p7 
GOMES, R.S.S., NUNES, M.C., NASCIMENTO, L.C., SOUZA, J.O., PORCINO, M.M. Eficiência de óleos essenciais na qualidade sanitária e fisiológica em sementes de feijão-fava (Phaseolus lunatus L.). Revista Brasileira de Plantas Medicinais, Botucatu, v.18, n.1, p.279-287, 2016. Suppl. 1. https://doi.org/10.1590/1983-084X/15_117

GURJAR, M.S.; SHAHID, A.; MASOOD, A.; KANGABAM, S.S. Efficacy of plant extracts in plant disease management. Agricultural Science, Toronto, v.3, n.3, p.425-433, 2012. https://doi.org/10.4236/as.2012.33050

JEFFREYS, M.F.; NUNEZ, C.V. Triterpenos das folhas de Piranhea trifoliata (Picrodendraceae). Acta Amazônica, Manaus, v.46. n.2, p.189-194, 2016. https://doi.org/10.1590/1809-4392201504572

LAGROUH, F.; DAKKA, N.; BAKRI, Y. The antifungal activity of Moroccan plants and the mechanism of action of secondary metabolites from plants. Journal de Mycologie Médicale, Lausanne, v.27, n.3, p.303-311, 2017. https://doi.org/10.1016/j.mycmed.2017.04.008

LAZAROTTO, M.; MUNIZ, M.F.B.; BELTRAME, R.; SANTOS, Á.F.; MACIEL, C.G.; LONGHI, S.J. Sanidade, transmissão via semente e patogenicidade de fungos em sementes de Cedrela fissilis procedentes da região sul do Brasil. Ciência Florestal, Santa Maria, v.22, n.3, p.493-503, 2012. https://doi.org/10.5902/198050986617

LORENZETTI, E.R.; MONTEIRO, F.P.; SOUZA, P.E.; SOUZA, R.J.; SCALICE, H.K.; DIOGO JUNIOR, R.; PIRES, M.S.O. Bioatividade de óleos essenciais no controle de Botrytis cinerea isolado de morangueiro. Revista Brasileira de Plantas Medicinais, Botucatu, v.13, p.619-627, 2011. Special Issue. https://doi.org/10.1590/S1516-05722011000500019

MACHADO, J.C.; MACHADO, A.Q.; POZZA, E.A.; MACHADO, C.F.; ZANCAN, W.L.A. Inoculum potential of Fusarium verticilliodes and performance of maize seeds. Tropical Plant Pathology, Brasília, v.38, n.3, p.21-217, 2013. https://doi.org/10.1590/S1982-56762013000300005

MACHINSKI JUNIOR, M.; SOARES, L.M.V.; SAWAZAKI, E.; BOLONHEZI, D.; CASTRO, J.L.; BORTOLLETO, N. Aflatoxins, ochratoxin A and zearalenone in Brazilian corn cultivars. Journal of the Science of Food and Agriculture, London, v.81, n.10, p.1001-1007, 2001. https://doi.org/10.1002/jsfa.882

MAGUIRE, J.D. Speed of Germination-aid in selection and evaluation for seedling emergence and vigor. Crop Science, Madson, v.2, n.2, p.176-177, 1962. https://doi.org/10.2135/cropsci1962.0011183X000200020033x

MEDEIROS, J.G.F.; ARAUJO NETO, A.C.; URSULINO, M.M.; NASCIMENTO, L.C.; ALVES, E.U. Fungos associados às sementes de Enterolobium contortisiliquum: análise da incidência, controle e efeitos na qualidade fisiológica com o uso de extratos vegetais. Ciência Florestal, Santa Maria, v.26, n.1, p.47-58, 2016. https://doi.org/10.5902/1980509821090

MORAIS, N.R.L.; OLIVEIRA NETO, F.B.; MELO, A.R.; BERTINI, L.M.; SILVA, F.F.M.; ALVES, L.A. Prospecção fitoquímica e avaliação do potencial antioxidante de Cnidoscolus phyllacanthus (müll. Arg.) Pax \& k.hoffm. Oriundo de Apodi - RN. Revista Brasileira de Plantas Medicinais, Botucatu, v.18, n.1, p.180-185, 2016. https://doi.org/10.1590/1983-084X/15_058

RIEGELHAUPT, E.M.; PAREYN, F.G.C. A questão energética e o manejo florestal da Caatinga. In: GARIGLIO, M.A.; SAMPAIO, E.V.S.B.; CESTARO, L.A.; KAGEYAMA, P. Y. (ed). Uso e conservação dos recursos florestais da Caatinga. Brasília: SFB, 2013. p.65-75.

SALES, M.D.C.; COSTA, H.B.; FERNANDES, P.M.B.; VENTURA, J.A.; MEIRA, D.D. Antifungal activity of plant extracts with potential to control plant pathogens in pineapple. Asian Pacific Journal of Tropical Biomedicine, Haikou, v.6, n.1, p.26-31, 2016. https://doi. org/10.1016/j.apjtb.2015.09.026

SEIFERT, K.A.; MORGAN-JONES, G.; GAMS, W.; KENDRICK, B. The genera of Hyphomycetes. Utrecht: CBS-KNAW Fungal Biodiversity Centre, 2011. 866p.

PEIXOTO SOBRINHO, T.J.S.; GOMES, T.L.B.; CARDOSO, K.C.M.; AMORIM, E.L.C.; ALBUQUERQUE, U.P. Otimização de metodologia analítica para o doseamento de flavonoides de Bauhinia cheilantha (Bongard) Steudel. Química Nova, São Paulo, v.33, n.2, p.288-291, 2010. https://doi.org/10.1590/S0100-40422010000200011

SOUZA, J.N.P.; CANDOTTI, J.G.; AMPARO, T.R.; COELHO, F.F.; RODRIGUES, I.V.; SANTOS, O.D.H.; MEDEIROS, L.F.T.; FURTADO, N.A.J.C.; SOUSA, H.C.; SOUZA, G.H.B. Bioprospecção das atividades antioxidante e antimicrobiana de espécies vegetais medicinais coletadas em Ouro Preto-MG. Revista Eletrônica de Farmácia, Goiânia, v.10, n.1, p.15, 2013. https://doi.org/10.5216/ref.v10i1.18635 
STEFANELLO, J.; BACHI, L.M.A.; GAVASSONI, W.L.; HIRATA, L.M.; PONTIM, B.C.Á. Incidência de fungos em grãos de milho em função de diferentes épocas de aplicação foliar de fungicida. Pesquisa Agropecuária Tropical, Goiânia, v.42, n.4, p.476-481, 2012. https:// doi.org/10.1590/S1983-40632012000400014

VENTUROSO, L.R.; BACCHI, L.M.A.; GAVASSONI, W.L.; CONUS, L.A.; PONTIM, B.C.A.; BERGAMIN, A.C. Atividade antifúngica de extratos vegetais sobre o desenvolvimento de fitopatógenos. Summa Phytopathologica, Botucatu, v.37, n.1, p.18-23, 2011. https://doi. org/10.1590/S0100-54052011000100003

VIEIRA, M.E.Q.; COSTA, C.; SILVEIRA, A.C.; ARRIGONI, M.B. Porcentagens de saponinas e taninos em vinte e oito cultivares de alfafa (Medicago sativa L.) em duas épocas de corte - Botucatu - SP. Revista Brasileira de Zootecnia, Viçosa, v.30, n.5, p.1432-1438, 2001. https://doi.org/10.1590/S1516-35982001000600007

WU, J.-H.; TUNG, Y.-T.; WANG, S.-Y.; SHYUR, L.-F.; KUO, Y.-H.; CHANG, S.-T. Phenolic antioxidants from the heartwood of Acacia confusa. Journal of Agriculture of Food Chemistry, Chicago, v.53, n.15, p.5917-5921, 2005. https://doi.org/10.1021/jf050550m

ZAUZA, E.A.V.; ALFENAS, A.C.; MAFIA, R.G. Esterilização, preparo de meios de cultura e fatores associados ao cultivo de fitopatógenos. In: ALFENAS, A.C.; MAFIA, R.G. (ed). Métodos em fitopatologia. Viçosa: UFV, 2007. p.23-51. 